\title{
PROGRESS IN CONSUMER CREDIT IN KENTUCKY
}

\section{B. J. LeNIHAN*}

Kentucky was one of the later industrial states to adopt a version of the Russell Sage Foundation Uniform Small Loan Law. As such, Kentucky represented one of the last bastions of boodle for the nefarious loan sharks. The throttling grasp of loan sharks upon Kentucky wage earners with each succeeding year pushed up personal bankruptcies until Kentucky became known as the Bankruptcy State and Louisville as the Bankruptcy Capital of America.

The sixteenth biennial report of the Kentucky Department of Labor covering the period from July I, to I932 to June 30, r934 shows the growth of wage earner bankruptcies in considerable detail. A chart therein illustrated that in 1930 in the United States, 96 out of 100,000 wage earners sought bankruptcy relief, whereas in Kentucky there were 320 , and in Louisville 800, per 100,000. The report further states: "The disparity is directly traceable to the loan shark evil growing out of lack of protective laws for the wage earners." In actual truth, when a victim became enmeshed in the loan shark toils, his only recourse for relief was "Bankruptcy or Death."

Like rats in a corner, the sharks fought viciously to keep Kentucky as one of their fields of exploitation. Through crude but still clever devices-such as dual note forms, agency and brokerage operations, phony merchandise purchases, forced insurance sales, and other equally deceitful methods-the loan sharks carried on their operations boldly throughout the entire Commonwealth. They placed their offices in prominent business locations in all the larger towns throughout the state.

In addition to the brazen and openly operating, organized loan sharks, there were literally thousands of small "pocket lenders" operating in the offices and plants of industries and commercial establishments all over the state. These "pocket lenders" had somehow acquired from several hundred to several thousand dollars which they usually loaned to fellow employees at rates similar to the openly operating sharks. They felt encouraged by the complacency of the general public toward usury and while far less publicized than the commercial lender, they made their sizable contribution to the misery and destitution that was the lot of so many thousands of Kentucky citizens.

To understand why such a dreadful expression of man's inhumanity to mas should exist in this supposedly enlightened stage of human progress, one has to realize the tremendous fear of debt and the deep rooted prejudice against money lending which dates back to the biblical days and far beyond. It is to this fear and ignorance and this deep and stupid prejudice about money lending, that the evils of loan sharkery in America and Kentucky can be laid.

- President, Time Finance Company, Louisville, Ky. 
There is a startling and disturbing lack of progress by educational institutions and industrial brains in educating the masses of the world, and of America, about the economic facts of life for the borrowing and lending of money. Great strides have been made by those engaged in the business in selling the general public on effective use of consumer credit as it applies to the purchase of consumer durable goods. In fact, consumer credit has grown so rapidly in America in the past three or four decades that it has lifted the level of prosperity and well being of our average citizen beyond the fondest dreams of even the wealthy of just a few generations ago and certainly to the highest level in the entire history of humanity. But even this fabulous growth of consumer credit financing of purchases has been accomplished through selling rather than education. There are still far too many consumers unable accurately to determine financing costs or to make a correct comparison between discount finance rates and cash lending charges.

The oldest uniform small loan laws of the United States are now entering their fourth decade of existence. Some new states have been added, in this year 1953, to those which have satisfactory laws governing the lending of money to consumers. Thankfully, these new states and many of the older ones have adopted new laws or revised old ones, which have placed loan ceilings at more realistic levels in the light of modern needs than the $\$ 300$ ceiling which was the standard years ago, and which still prevails in several states such as Kentucky. These modernized new and old regulatory loan laws not only provide a wider borrowing service to the people of their respective states but also lower over-all costs, saving American borrowers many millions of dollars each year.

With all these new legislative advances and the obviously greater perception of the need of a broad, fair and reasonable-cost consumer cash lending system, there still prevails in the minds of a large segment of America's population very much of the fear, ignorance, and prejudice about borrowing and lending money that prevailed as of old.

As a matter of fact, it is this very same public attitude which, in such a large measure, permitted the existence of the terrible and demoralizing loan sharkery that existed in Kentucky and other states prior to the passage of adequate, protective laws. It was the apathetic and indifferent attitude of so many Kentucky business, civic, political, judicial and educational leaders-the so-called enlightened public-which, in its self-satisfying knowledge that if it ever needed money it could secure that money at a bank at a so-called 6 per cent rate of interest, led them to ignore the utterly pitiful predicament of the masses of Kentucky citizens who had no means to secure a loan at a bank. It is no tribute to our secondary and higher institutions of learning that they had failed to educate the so-called enlightened public and leadership in Kentucky to a realistic appreciation that it is impossible for a bank or any other lending institution to lend money in small amounts to people of little means with no commonly acceptable bank collateral at a 6 per cent pure, or discount, rate of interest. So, untold thousands of Kentuckians were delivered over to the 
misery and destitution of patronizing the illegal lenders who, in ignorance or predatory greed, gouged them with unconscionable charges ranging from 200 to as high as $\mathrm{I}, 000$ per cent per annum.

The vacuum thus created by this shameful ignorance, prejudice, and lack of realistic economic knowledge literally offered an engraved invitation to the greedy bootleg lenders to mulct the masses. The tremendous profits garnered by these hundreds of openly operating loan sharks and their thousands of pocket lending satelites emboldened them and made them impervious to the sporadic and impractical efforts exerted to halt their operations. Publicity, legal actions, and even arrests, deterred them but little. Like the whiskey bootleggers of the prohibition era their profits were so great that they were able to employ expert, if not ethical, legal counsel to extricate them from entanglements in which occasional efforts rigidly to enforce the usury laws engaged them. Their profits were so great, and their patronage to fee-minded magistrates so consistent that these elected representatives of the people were almost their employees. Ironically enough, the very laws of the state itself were so often on their side that whenever they exerted legal pressure to extract their "pound of flesh," they were able to do so with little risk of loss. Those are the facts and that was the situation that prevailed with increasing incidence in the sovereign Commonwealth of Kentucky, as it grew to increasing industrial importance in the decades preceding 1934.

Repeated efforts were made at legislative sessions by a small but truly enlightened core of newspaper editors, legislators, public officials, union leaders, and civic minded citizens, who clearly perceived the economic enslavement of the masses of Kentucky wage and salary earners caused by the lack of an effective law-a law which would on the one hand protect small borrowers, and on the other, invite honorable and ethical capital into the field adequately to service the financial needs and desires of the great mass of people. But, at each legislative session, the excessive profits of the illegal lenders enabled them to raise substantial slush funds. Not only were the votes of legislators bought to defeat the passage of a decent regulatory law, but money was freely spent to inflame the ignorance and prejudice of many sincere minded legislators and people of influence and to persuade them to stand against the law which would have wiped out the evil.

Here is where the leadership of educational institutions and commerce and industry failed miserably and unwittingly played the game of the loan sharks and left the masses of our citizens in economic jeopardy and despair. For, had the socalled "enlightened" leaders of our state been aware of the economic facts of consumer borrowing they would have seen through the false propaganda of the loan sharks, who, while charging up to 1,000 per cent per year themselves, threw up the horrible smoke screen of " 42 per cent usury."

In confirmation of loan shark legislative tactics to insure unmolested operation of their evil racket, here is an editorial quotation from the "New Era," which carried 
on its masthead, "Kentucky's Oldest and Greatest Labor Paper." It is the issue of January 16, I932:

Once-just once-Kentucky almost did its duty to the thousands of worthy citizens who cannot help themselves. In 1928 the Kentucky legislature passed a small loan bill, only to have it vetoed by Governor Sampson.

Before-long before-the 1928 session of the legislature, all of the loan sharks in Paducah, Kentucky, received a comprehensive letter from the local collector for the high rate loan shark combine. At that time there were twenty-five loan sharks in Paducah for a population of about 25,000 .

After this legislation failed on account of the veto of Governor Sampson, citizens of Paducah with the welfare of the community at heart conducted a local campaign against the loan sharks. For the time being the loan sharks "crawled into their hole"-but now they are in full swing again. A reduced reproduction of the exact letter of the Paducah Collector for the loan shark combine is reproduced on this page. It is dated from Miami, Florida, February 25, I927 and it reads as follows:

Paducah High Rate Loan Men,

Gentlemen:

January, 1928 we will be confronted with the supreme fight in Kentucky, to determine whether the $3 \frac{1}{2} \%$ people dominate Kentucky or whether we are to continue operating our business.

There is no such thing as operating where the $3 \frac{1}{2} \%$ bill is passed and in force. This has been definitely proven this year.

Only 4 states will assemble their legislatures in 1928 . All the states of the Union are in session this spring except the 4 that will assemble next January.

One of these 4 (Virginia) is already under the $3 \frac{1}{2} \%$ rule leaving only 3 states for them to centralize on in their fight in the spring of 1928 .

They have openly boasted that they will pass the $3 \frac{1 / 2}{2} \%$ Bill in Kentucky in 1928 or forever abandon the field. Their final effort will be made in the 1928 legislature to either pass the Bill or give up the right for all time thereafter.

More than 30 states will be dominated by the $3 \frac{1}{2} \%$ interest after the present sessions adjourn.

They openly boast as to what they are going to do for us next time the legislature meets.

Now are we going to surrender or are we going to fight them? To fight them we must have our organization working before they get retrenched. We can whip them if we get together and not wait till next January to start our fight.

Just ask ourselves is my business worth putting up a fight to continue operating. What would we do if we were out of the loan business. For we surely will be out if this $3 \frac{1}{2} \%$ Bill is passed.

Now here is the solution. Start right now put aside each month this year a certain amount. Say $(\$ 20)$ per month for the next Io months. This will give each office $\$ 200$ in hand by January the Ist.

We can do this and never miss it and have it ready at any moment it is needed. This will give Paducah $\$ r, 400.00$ to make what will be our last and final stand. And if we do this we will win but if we neglect this the other factions will win. And we will be working for some concern at about $\$ 80$ per month for a living. 
The reason I suggest this method is simply this. We are always in a strain financially in January. December calls for very heavy loans. Our business rarely ever remits in December.

In January we have a license to pay and collections are always slow in January. Bad weather and bankrupts galore usually follow.

Therefore, if we begin now our business will be saved and we can continue to make a living out of the loan business. But if we neglect and fall down then we are doomed. Not one of us but what make bad loans to the amount of $\$ 20$ every month and never miss it. Then why not charge out $\$ 20$ each month while we are doing business and be ready for the fight that is just ahead. We are not guessing at this. We know.

So trusting you boys will each adopt this method for it is the easiest and surest way to be ready when the time comes.

I can assure you that my offices will put in dollar for dollar for what the rest put up per office.

Sincerely,

$$
\text { /s/ J. V. Jones }
$$

When the $240 \%$ loan sharks talked among themselves, it is a different story than the one they used to fool the public. When speaking of their business for the benefit of the public, it is usually a story about what fine fellows they are and how they are helping the public. But how different when they have their own "Tea Parties." The letter reproduced here frankly states that they would not be able to operate if Kentucky adopted adequate small loan regulations like 26 other states have done.

... These high rate loan sharks who charged the needy borrower in Kentucky $240 \%$ seemed to be concerned not about the borrower-but about themselves and their high rate business. And then they begin to raise money for legislative purposes-just how this money is used is another question. But the fact remains that they raised the money to prevent the passage of legislation, at least according to the information in the attached reduced reproduction of the letter of the Paducah Collector for the $240 \%$ loan shark combine-and they made plans one whole year ahead.

The above editorial comment from an old established labor union newspaper reveals the major facets of the problem confronting the advocates of a proper regulatory Kentucky law. Perhaps more importantly, the reproduced letter of the loan shark slush fund collector bares in all its naked ugliness the vicious and greedy self interest of the loan sharks. It should be noted that the collector's letter was dated in February, I927, and while the legislature in 1928 enacted a regulatory small loan law, it was vetoed by the then governor.

The date of the "New Era" issue was January 16, I932, shortly after the biennial session of the legislature had started. The loan shark collector's letter was well publicized and distributed during this legislative session. But, this revealing letter and its shocking contents did not turn the tide, for the small loan law again was badly defeated in both Houses. Seemingly, the position of the Kentucky loan sharks was impregnable. It was a thoroughly disillusioning and disastrous defeat for the forces of good. There was a great deal of despair in the leadership of the small loan advocates. The chicanery of the loan sharks and even of some local labor 
leaders who piously professed a desire to protect their membership from " 42 per cent usury"-added to the ignorance, indifference, or lethargy of the business, educational and civic leadership of the state-seemed an utterly insurmountable barrier. Still some small loan advocates persevered, and educational efforts were continued.

By the fall of 1933 the situation in the industrial cities of the state became so intolerable that a great crescendo of protests arose. It appeared that at long last the leadership of the state was properly enlightened. Citizens' committees were formed. A great newspaper campaign was waged. Day after day the press portrayed in its columns the story of misery, destitution, and gouging of citizens. Public officials became aroused.

When the legislature met in January, I934, the battle lines were drawn. On the one hand, the belatedly aroused indignation of the state's leadership-and on the other hand, the evil vote-buying sharks and their unwitting allies, the sincere but benighted and prejudiced stooges. Some of these stooges may not have been so sincere or unwitting, as the following editorial discloses. This editorial appeared in the "Kentucky Post" of Covington, dated February ıo, r934:

Just as expected, opposition to the Bill that will drive loan sharks out of Kentucky and keep them out is being led by Pete Campbell, who is recorded on the Lobbyists' Book at Frankfort as Secretary and Treasurer of the Kentucky State Federation of Labor.

Every time within recent years that remedial Small Loan legislation has been proposed, Pete Campbell has fought it. There must be a reason. Campbell denies that he is being paid by the loan sharks. We have to take his word for it.

Pete Campbell has a perfect right to oppose antiloan shark legislation as a private individual, but when he tells a House Committee that he is speaking for organized labor, then we are going to call his bluff. Pete Campbell does not speak for organized labor in opposing this loan shark Bill and we have the word of William Green, President of the American Federation of Labor to prove it.

The remedial small loan legislation now being considered at Frankfort has the written approval of the President of the American Federation of Labor, just as it did two years ago. We have Mr. Green's letter over his own signature to prove it.

The "Kentucky Post," whose crusading Editor, D. E. Weaver, played such a vital role in the final enactment of the Kentucky law, came out with another editorial on February I9, 1934. We quote it below:

Before the Kentucky Legislature is a Bill which will effectively exterminate the loan sharks which have been preying on Kentucky wage earners for so many years by charging usury at the rate of 250 to $500 \%$ a year.

As always, there is strong opposition to the Bill, from the loan sharks themselves and their paid Lobbyists. Loan sharks make a lot of money-as they should at their interest rates-and are generous contributors to certain campaign funds.

By generosity such as this, they hope to beat the Bill sponsored in the House by Christopher Gottschalk of Kenton County, and in the Senate by Fred A. Harrison of Williamstown. 
The Bill would put legal recognition on the fact that a small loan firm making loans without security must charge more than the present legal rate of $6 \%$ in order to exist. Opposition to the Bill is based on the theory that $42 \%$ a year is too much interest. Perhaps it is, but it is vastly superior to $250 \%$, the amount the loan sharks have been charging and will charge as long as they are tolerated.

Still another leading Kentucky newspaper and a crusading editor came out shortly thereafter with a fighting editorial that put the issue with outstanding vigor and clarity to each member of the legislature:

\section{An Open Letter to the Kentucky General Assembly}

\section{Gentlemen:}

Believing that you, as representatives of the people of Kentucky, desire to help smash the vicious ring of loan sharks now engaged in bleeding thousands of working men and women of our state of approximately $\$ 5,000,000$ every year, nearly every dollar of which goes out of the state, we desire to present the following facts for your earnest consideration:

A meeting of representative loan sharks was held in Louisville Saturday afternoon, February $\mathrm{r} 7$, at which time plans were made to raise a slush fund which is to be paid to certain politicians to insure that certain members of the House and Senate will be ordered to vote against the Gottschalk-Harrison Bill. The assessment against each loan shark firm was set at $\$ 35^{\circ}$ and twenty-eight firms are included in the list, which would raise a fund of $\$ 9,800$.

... we believe you should know in advance that a slush fund is being raised to be spent at Frankfurt to BUY votes against the Gottschalk-Harrison bill.

Then the farmers of the state joined in the battle. The following news story appeared in the Louisville Herald-Post, February 5, 1934:

Support of the Kentucky Farm Bureau Federation, its thirty county units and its 8,000 affiliated farm women was pledged the Herald Post's campaign for remedial Small Loan legislation today by Ben Kilgore, Executive Secretary of the State Federation.

"We're for you 100\%" declared Mr. Kilgore in an interview. "We'll talk it up to our Representatives in both Houses of the Legislature and I'll lend my personal support at Frankfort toward passage of the Gottschalk Bill without amendment."

Virtually all of the newspapers in the industrial communities throughout the state took their editorial pens in hand and demanded that this vicious blot on Kentucky's honor and progress be removed for all time. On February 15, 1934, the Lexington Herald editorialized against "The cruel and grasping exploitation of those in dire need."

Through the long days of the legislative session, the battle was fought. The first test came and was successfully met. The House passed the fifth draft of the Russell Sage Small Loan Law by a small majority. The locale of the battle then moved to the Senate. Here, after weeks of skirmishing and literally hundreds of 
pages of newspaper publicity the law squeezed through by a narrow margin of two votes.

The battle then moved to the executive office. Here again tremendous pressures were built up from both sides. To his credit, the late Governor Ruby Lafoon saw the wretched plight of the people and the depraved viciousness of the loan shark evil. The legislation was signed and became law.

But the sharks-still fighting hard, still grasping for a last straw to continue their prosperous pillaging-carried the battle to the courts. They attacked the constitutionality of the law first in the state courts and then in the federal courts. They were defeated in both places. The masses of small Kentucky wage earners were at long last delivered from the toils of the sharks.

\section{What Has Happened Since the Kentucky Smali Loan Law Was ENACTED IN I934?}

Kentucky wage and salary earners, farmers, and small businessmen have steadily increased their use of small loan service. From a comparatively nominal use of the service the first year after the law was passed the volume of loans made and number of customers served has grown to rather vast proportions. In I935, the first full year the law was in operation, 38,709 Kentucky consumers borrowed $\$ 3,328,744$. In the year 1952, 251,586 Kentuckians borrowed $\$ 53,146,559 .^{1}$ The significance of these figures can be better appreciated when it is realized that the population of Kentucky has remained almost static during the period the Small Loan Law has been in existence. The population in the state in 1950 was $2,944,000$, an increase of a mere r00,000 over 1940. There are today in Kentucky approximately 700,000 family units. Since most small loans are made to husband and wife, it can be readily seen that small loan companies made loans in $195^{2}$ to the extent of more than one third of the family units in the state.

To present a well rounded and well documented picture of the conditions which prevailed prior to the passage of the law, and some comment as to how effectively the law has manifested its benefits, the opinions of several qualified persons were invited.

First, there follows a brief commentary from Mr. James T. Norris, now President and Editor of the Ashland, Kentucky Daily Independent. Mr. Norris' paper and he were among the newspapers and editors who waged the winning battle.

It is now nearly 20 years since the Kentucky Small Loan Law was enacted. The Law served to end a period of almost fantastic abuse of the public through usury in Kentucky. In industrial communities such as Ashland, the salary and wage buyers and other loan sharks under various names, preyed upon the public without restraint.

The interest and other charges often reached the rate of $1,000 \%$ a year. There was discrimination and all forms of abuse, bringing misery and ruin to many worthy people of modest income. The Law then in force gave no protection.

1 These figures are taken from the Annual Report of Small Loan Company Operations prepared by the Department of Banking of the State of Kentucky for the years mentioned. 
The present Law came as a result of a united demand from employers, newspapers and workers' groups. It gives me pride to recall that this newspaper had a small but active part in ending that abuse.

Judge Emmet R. Field is General Counsel of the Legal Aid Society of Louisville. Judge Field's twenty-five years with this vital civic agency and his constant daily contact with the legal problems of people of small means, encompass the period immediately preceding and following the passage of Kentucky's law and ably fit him to comment on the conditions prevailing before and after the law's enactment.

For two decades preceding adoption of the Kentucky Small Loan Law, problems engendered by loan sharks became progressively intense. Wage earners who were fast becoming the largest single group, with growing industrialization of the state, found themselves unable to secure loans at banks. Their only recourse, under the circumstances, was to patronize the uncontrolled illegal lenders who tock ruthless advantage of their necessities. As industrialization progressed and wage earners increased throughout America, states surrounding Kentucky adopted regulatory Small Loan Laws. Kentucky, lacking enforcable lending restrictions, remained one of the last lush garden spots for the bootleg lenders to entice their prey and carry on their unconscionable operations.

At the peak of their piracy, there were about roo illegal lenders operating openly in Louisville. Smaller cities, such as Lexington, Covington, Newport, Paducah and many others, were havens for proportionately large numbers of these money lending Law breakers.

It was conservatively estimated that the yearly take of these illegal lenders in Kentucky exceeded $\$ 5$ million. Kentucky fast became a state with one of the highest personal bankruptcy ratings in the union. The destitution and misery spread by their operations was incalculable. Sporadically in Louisville and elsewhere in the state, drives were put on by newspapers, employers, attorneys, and other interested groups, but they were completely unavailing in effecting any permanent cure or removal of the blight.

At several sessions of the Legislature, attempts were made to secure passage of remedial laws. But, largely due to the ignorance and misunderstanding of the legislators and the general public as to the merits of such legislation, these attempts ended in failure.

Meanwhile, garnishment of wages continued to climb and many employers unwittingly abetted the enslavement of their personnel by threat of discharge if wages were attached. Great numbers of borrowers, even when legal assistance was available, submitted in silence and paid the lender's price, lest their wages be seized and their employment lostor lest they be blacklisted and deprived of their only source of cash in future emergencies. The growing wave of bankruptcies swept away legitimate debts which might have been paid. And an appallingly large segment of the population reduced food on their family tables and put off the landlords to meet the demands of the lenders. The whole economy was raided and damaged. Finally, the tremendous economic changes which swept the country into the growing complexities of intensive industrialization brought a growing awareness of the problems of securing cash credit in times of emergency. The excellent experience from regulatory Laws adopted in a large majority of the industrial states of the country, offered salutary answers to the problem. Gradually, the need for the higher interest charges permitted by these Laws, in order to attract sufficient honorable capital into the field to meet the borrowing necessities, penetrated the prevailing ignorance and misunderstanding. 
Finally, in 1933 , an immense campaign to drive out the loan sharks, and publicize the need for a recognized regulatory Law was inaugurated in Louisville and various other of the affected communities in the state.

After a bitter and prolonged battle, the Legislature finally adopted the Kentucky Small Loan Law by a very narrow margin.

With the enactment of this Law came the dawn of a new and beneficial economic era for the wage earners and the small borrowers of the Commonwealth. The loan sharks died hard and some endeavored to continue their operations under new and stealthier devices. Attacks from questionable sources were made upon the Law at subsequent sessions of the Legislature. But, the beneficial effects of the new Law manifested themselves so strongly and completely that these attacks proved futile.

In the almost 20 years elapsed since the Law went into effect in June, 1934, the economic well being of Kentucky wage earners has steadily advanced. With each passing year, the Kentucky Small Loan Law has proven its merit. Today, in every corner of the commonwealth, wage and salary earners have a legal, honorable and recognized source of cash credit available to them-to meet their emergencies and to satisfy their needs and desires. The volume of consumer use of this service has grown with each year. The companies engaged in providing this service have proved themselves honorable and cooperative in their methods.

So far as the Legal Aid Society of Louisville is concerned, we have always enjoyed the finest cooperation from the companies engaged in the business in solving the problems of any borrower in legitimate difficulties. The difference between the economic conditions which prevailed for small borrowers in Kentucky before and after the passage of the Kentucky Small Loan Law, is truly the difference between night and day. To look back at the newspaper stories and the conditions which prevailed prior to 1934 is like re-living a hideous nightmare. And because the Kentucky Small Loan Law has proven the inherent honesty of the vast majority of our citizens, banks and other lending institutions have entered the consumer credit field with the result that consumer borrowers now have greater sources of credit available to them than previously, or than even presently prevails for commercial borrowers.

To present the viewpoint of businessmen as to what effect the Kentucky Small Loan Law has had on the economy of the state, we solicited the comment of Mr. Dewey Daniel, President of the Peoples Bank, Hazard, Kentucky, and President of the Kentucky Chamber of Commerce. Mr. Daniel comments as follows:

The passage of this Law in 1934 represents one of the major economic advances for our Commonwealth since its founding. The Law almost instantly shattered the dread shackles of usury which excessively burdened so many thousands of our citizens. By providing a state regulated loan service at reasonable rates, this Loan Law gave a new birth of economic freedom to thousands of wage earners. In the mines, in the factories, and in all industrial and commercial activities employees had a weight lifted from their shoulders and had a new and sound method of securing credit at their disposal.

As a result, these thousands of Kentuckians assumed far greater importance as economic units in their communities. With sound credit at reasonable rates, they could solve their financial difficulties, pay accumulated debts, and make purchases from merchants in their cities and towns. It is axiomatic that anything that helps the consumer helps business. So, the whole community of our state has benefited. 
It is significant that in the 20 years since its passage, no serious attack has ever been made by any reputable group on the Small Loan Law. This would certainly confirm the general effectiveness, and the public's appreciation, of the Act. Under no circumstances would employees, employers, and businessmen want to revert to the borrowing and lending conditions which existed prior to 1934 .

To give further light from an unbiased, qualified source as to conditions prevailing before and after enactment of the law, here are the comments of the Honorable Charles W. Burnley, present Speaker of the House of Representatives, Commonwealth of Kentucky. As a seasoned legislator, as a member of a labor union, and as holder of the highest office in his branch of the legislature, Representative Burnley can speak authoritatively of the situation:

Prior to 1934 when the Kentucky Petty Loan Act was passed by the Legislature and officially signed into Law by the then Governor Ruby Lafoon, the City of Paducah and most other industrial communities of the state were plagued with loan sharks. These sharks levied charges ranging from $240 \%$ per year upwards. In Paducah, the minimum rate for whites was $240 \%$, for colored $360 \%$ per year. Sharks in the main preyed upon working men and salaried employees. Once a person fell into the clutches of the sharks, it was virtually impossible for him to extricate himself short of bankruptcy or death. The main device by which the shark enmeshed the victim was the bar against partial principal payments. Except on the larger loans the shark would not accept partial payments.

Since the shark's victim operated on such a narrow margin between income and expenses, he rarely had enough money to pay the total principal on even the smallest loan, so he went on indefinitely paying interest only, which the shark thoroughly welcomed. Railroad men were an especially choice prey of the sharks. They were an extremely good risk because they were vulnerable to garnishment and they always had at least two weeks' wages coming under the railroad method of paying personnel. Representatives of the sharks were regular payday visitors at the huge Illinois Central Railroad Shops in Paducah as well as other industrial plants in the community. They came to collect from victims whom they would not trust to come to their office, as well as to solicit additional business.

Since the passage of the Kentucky Small Loan Law, all this has been changed. Now the wage earners and salary workers in our community and throughout the state can, through small loan licensees, secure loans in such size as to effectively and permanently correct their financial problems. They can secure these loans at reasonable rates that are only a slight fraction of loan shark charges. They can repay the loans in installments, permitting an orderly liquidation of the debt. Through strong competition, they are assured good service and helpful advice on almost every family and personal money problem.

The Law has worked well, and would work possibly even better if the ceiling on loans was increased from $\$ 300$ to at least $\$ 500$. The higher ceiling is needed because of the greatly reduced value of the dollar since the enactment of the Law in 1934. In the event the ceiling was raised, the rates on loans above $\$ 300$ could be substantially reduced, which would make the Law even more effective and advantageous for the citizens of our state.

Henry Ward, the author of the following statement, first ran for the legislature on a platform to eliminate the loan shark evil in the state. As a newspaper reporter on the Paducah Sun-Democrat, he saw at first hand in his "daily beat" coverage of 
the courts of Paducah and McCracken County, the misery and destitution the sharks were inflicting on the wage earning citizens of his community. As a freshman Representative in 1934 Legislature, Henry Ward played one of the most prominent roles in bringing the law to a reality. His participation in the successful fight to drive out the sharks has kept him in public service almost constantly since. He subsequently became Editor of his paper and was re-elected repeatedly to the House of Representatives and thereafter to the State Senate. Leaving the legislative and newspaper field, he became Commissioner of Conservation for the State of Kentucky and still serves in that capacity. Mr. Ward states:

A three-year campaign to stamp out the evil of loan sharks in Paducah produced the conclusion that an answer could not be found without a new state Law and created my first interest in serving as a member of the Kentucky General Assembly.

As a young newspaperman in 1929 , I became interested in an effort to unfasten the fangs of the loan sharks from the throats of thousands of poor people in Paducah who had become their victims. The Paducah Sun-Democrat, for which I was then a reporter and later associate editor, sponsored the campaign against them. I was assigned to writing the stories and helping to make investigations.

There were 20 or more loan sharks operating in Paducah then, many of them having been attracted there because Paducah has the great Railroad Shops of the Illinois Central System. Their methods amazed and shocked me.

I will never forget the story of one negro man I ran across in one of my investigations. His wife was about to have a baby. On his meager salary, he had not been able to save anything for that event. When the time arrived, he could not get a doctor to come to their home except on a promise to pay $\$ 15$ in cash. He did not have the cash, and of course he could not borrow from a bank, because he had nothing to pledge as security for a loan. So he went to a loan shark and got the \$15, with the understanding that he would have to pay $\$ 3$ a week as interest, $\$ 1$ for each $\$ 5$ of the loan. The only record of how much and how long he had been paying that rate of interest when I got his story was the fact that the child for whom the original $\$ 15$ was borrowed was now eight years old. He still owed the $\$ 15$, for he had never been able to save enough to pay off the principal.

That was the favorite method of the sharks-to get a borrower in debt to such an extent that he could never pay the full amount of the loan plus the interest payments required each week or month.

In our newspaper campaign, we employed attorneys and took several cases to court under the State's Usury Law. But the victims never had records, for the sharks never gave them receipts or other evidence of the facts covering their loans. The law provided only for recovery of amounts paid in excess of the legal interest of $6 \%$, and to provide proof suitable to meet the test of the courts was in most instances impossible.

It became apparent to me and to many other Kentuckians that the state needed a Law that would recognize that many persons who need to borrow money could not get it from the banks at the established interest rate of $6 \%$. They needed another means of securing credit, under strict supervision and control.

Finally, here is the considered judgment of the present Governor of the Commonwealth-the Honorable Lawrence W. Wetherby-on the beneficial effects of 
Kentucky's regulatory law. As Lieutenant Governor for three years and Governor for the past four, Governor Wetherby is in a most authoritative position to determine the economic benefits which have come to the people of Kentucky as a result of the passage of this legislation.

When Kentucky's Sr all Loan Law was enacted by the Legisiature and signed by Governor Ruby Lafoon in 1934, I was still in school, so I have no direct, intimate knowledge of the borrowing and lending conditions which existed in the Commonwealth previously. In the almost 20 years it has been in existence, there has been a vast improvement in the economic welfare of Kentucky salary and wage earners. There occurred a very large decrease in wage earner garnishments and bankruptcies. Lending money to small borrowers of our Commonwealth became a legal, dignified business, for both debtor and creditor. The interest saving to borrowers from the excessive charges of the illegal lenders has been tremendous. Our Law requires the Commissioner of Banking to report to the Governor each year on operations of the small loan licensees. Each Report, for the past I9 years, indicates a steadily rising popularity and use of the small loan service. The merit of this service has been highly regarded by our Banking Commissioners, and it certainly can be safely assumed that the increased patronage accorded it by so many thousands of our citizens implies their approval also.

The almost negligible number of legal actions disclosed by the Banking Commissioner's Annual Reports further implies that the vast majority of our citizens are thoroughly honest and do highly respect their obligations. It also speaks well for the helpful and considerate business practices of small loan licensees that in granting and collecting many thousands of loans totaling many millions of dollars each year, there is only rare resort to legal action.

The state licensed small loan organizations of Kentucky have made a splendid contribution to the economic welfare and progress of our citizens and our Commonwealth. The Small Loan Law is one of the most progressive and beneficial Laws enacted by 'our Legislature in the past several decades.

The above analyses from such authoritative and diversified sources give a calm, clear appraisal of the merits, benefits, and absolute indispensability of regulatory consumer loan laws that should be sufficient to satisfy even the most dubious. Certainly, it is most convincing proof that in no other private enterprise way can the monetary needs and desires of the masses of people in our modern, highly industrialized society be met.

As indicated heretofore, it is extremely difficult to eradicate from the minds of all too many people of supposed inteiligence, the doubts they hold regarding the necessity of such regulatory Laws, and more particularly the necessity of charges higher than commercial bank rates successfully to meet the problem. This unawareness of, or prejudice against hard economic facts, should be a challenge to the educational and business leadership of our country to bring about a better understanding of the charges and systems necessary to a successful effective cash lending service. It is a challenge that should be met forthrightly and forthwith.

To the credit of the educational field, some considerable efforts have been initiated to bring enlightenment and understanding and to eliminate this discouraging 
illiteracy about consumer credit economics. The Better Business Bureaus of America, with the cooperation of the National Consumer Finance Association and trade associations representing other fields of cash lending, have joined with secondary school leaders to disseminate textbooks and materials explaining the use and charges of consumer borrowing and financing. Some of the leading universities of the country have, in the past several years, held Consumer Credit Conferences, in which leaders of all segments of the consumer credit field have participated along with educators, to dispel the darkness. Columbia University, University of Pennsylvania, New York University, Minnesota University, Indiana University, Michigan State, and many others are joining the ranks to teach and explain consumer credit. All of these efforts are but a drop in the bucket. Much, much more must be done before there will be common understanding of the most common and important daily needs in the lives of American citizens. The fear of debt and prejudice against its use, users, and dispensers, must one day be eliminated from the American scene.

It should be noted that after the adoption of the Kentucky law, when use of small loan service spread so rapidly and eloquently proved the inherent honesty of most people of modest means, a growing number of banks and other lending institutions entered the consumer loan field. While small loan operators are firm in their belief that no other private tax-paying lending system can replace them in their vital service to the masses of people of small means, this has created healthy competition and has given borrowers a wider choice of sources to borrow money than had ever been dreamed of in the past.

As further evidence of the grave lack of knowledge about consumer lending and financing, there has been a rapidly growing tendency in recent years to exploit non tax-paying and subsidized co-ops which, by reason of their freedom from the burden of taxation and by subsidization otherwise provided them, are able to lend at lower rates than private, tax-paying lending institutions. Many of Kentucky's and America's leading business institutions are fostering and subsidizing these tax exempt employee cooperative lending facilities.

This economic unawareness, which permits and encourages promoters of these tax exempt cooperatives, and their unwitting allies, the business organizations which subsidize them, closely parallels the economic ignorance which permitted the loan sharks and their stooges to keep the shackles of misery and destitution on the people of small means in Kentucky and other states prior to the passage of regulatory laws. The passive permissiveness of the leadership of Kentucky and America that enabled the loan sharks ruthlessly to exploit the unprotected masses can equally permit the ruthless exploitation of the masses and everybody into a system of society which they neither yearn for nor desire.

A little knowledge is a dangerous thing. Little knowledge permitted the loan shark evil to long exist-and it presently permits this other danger heavily to impend. 